\title{
Kidney myxosporean parasites in red drum Sciaenops ocellatus (Sciaenidae) from Florida, USA, with a description of Parvicapsula renalis n. sp.
}

\author{
Jan H. Landsberg \\ Florida Marine Research Institute, State of Florida Department of Natural Resources, 100 Eighth Avenue Southeast.
} St. Petersburg, Florida 33701-5095, USA

\begin{abstract}
Two species of myxosporean parasites were found in red drum Sciaenops ocellatus (L.) from Florida, USA. These species were located in the posterior kidney and are confirmed as Henneguya ocellata Iversen \& Yokel 1963 and Parvicapsula renalis n. sp. Intraluminal developmental stages and mature spores of $P$. renalis $\mathrm{n}$. sp. were observed. In front view, mature spores were elongate $(9.5 \times 3.55$ to $4.7 \mu \mathrm{m})$, asymmetrical and slightly curved, with one valve slightly larger than the other. The pyriform polar capsules $(3.0 \times 2.0 \mu \mathrm{m})$ pointed in towards each other and were situated in a raised 'head' region that appeared to be separated from the spore cavity by a 'membrane' The polar filaments had 5 to 8 evenly spaced coils.
\end{abstract}

KEY WORDS: Kidney - Myxosporean - Parasite - Parvicapsula renalis n. sp. Red drum Sciaenops ocellatus

\section{INTRODUCTION}

The Florida Department of Natural Resources' (FDNR) Florida Marine Research Institute (FMRI) is conducting a long-term research program to determine the feasibility of increasing depleted feral stocks of red drum Sciaenops ocellatus (L.) (Sciaenidae) by releasing, into the wild, fish cultured at the Stock Enhancement Research Facility (SERF) at Palmetto, Florida, USA. In this program, cultured, cultured and tagged-released, and feral fish are routinely screened for parasites so that baseline information can be developed on the differences and similarities in the characteristic parasite fauna of the different groups. Some of these parasites could become pathogenic in mariculture systems. This study was undertaken as part of the parasite-classification survey and discusses 2 species, Henneguya ocellata Iversen \& Yokel 1963 and Parvicapsula renalis n. sp., found in the kidneys of feral red drum.

\section{MATERIALS AND METHODS}

Cultured fish were obtained from SERF during November 1991 and during January, May and July 1992. Cultured, tagged-released fish and feral fish were obtained from Bishops Harbor $(\mathrm{BH})$, Manatee County, Florida, in March, April and July to September 1992 and were obtained monthly from Murray Creek, Volusia County (VC), Florida, from November 1991 to November 1992. Necropsies were performed on 117 fish as part of the parasite-classification survey. Tissue portions of 5 to $10 \mathrm{~mm}$ were taken from gill, pseudobranch, posterior kidney, swim bladder, gall bladder, liver, urinary bladder, stomach, ceca, anterior and posterior intestine, spleen and musculature. Fresh squash preparations of these tissues, as well as of skin and fin scrapings and of blood, were examined by light microscopy for myxosporeans. Parallel evaluations of tissues were also made from stained smears or histological preparations. Smears were air-dried, methanol- 
fixed, and stained with Giemsa: 0.1 M phosphate buffer (1:1, pH 7.4) for 20 min. Stained slides were rinsed with $0.1 \mathrm{M}$ phosphate buffer and air-dried for later evaluation.

Histological slides were made from tissues that were fixed in $5 \%$ paraformaldehyde in $0.1 \mathrm{M}$ phosphate buffer, dehydrated in a graded ethanol series, and embedded in JB-4 glycol methacrylate resin. Sections were cut to $3.5 \mu \mathrm{m}$ on an LKB 2218 Historange microtome and were stained in Weigert's hematoxylin and eosin (H\&E), in periodic acid Schiff's hematoxylin metanil yellow (Quintero-Hunter et al. 1991), or in thionin stain adapted to glycol methacrylate (P. Nagle \& I. QuinteroHunter, FMRI, unpubl.). Representative samples were deposited in the U.S. National Museum (USNM) and in the FDNR Marine Invertebrate Collection at FMRI (FSBC I).

Fresh specimens of Parvicapsula renalis $\mathrm{n}$. $\mathrm{sp}$. were viewed and photomicrographs made with differential interference contrast optics. Measurements of fixed spores in histological section, taken at a magnification of $\times 1000$ and given in $\mu \mathrm{m}$, are reported as the mean and range (in parentheses) for both Henneguya ocellata and $P$. renalis n. sp. Fish standard lengths are given in $\mathrm{cm}$.

\section{Description of Parvicapsula renalis n. sp. (Fig. 1)}

Host: Red drum Sciaenops ocellatus.

Locality: Atlantic Ocean at Murray Creek, Volusia County, Florida, USA $\left(29^{\circ} 08^{\prime} \mathrm{N}, 80^{\circ} 53^{\prime} \mathrm{W}\right)$. Salinity was 22 ppt

Site of infection: Lumen of posterior kidney proximal tubules.

Type slides: Syntype slides of histological sections of posterior kidney stained in hematoxylin and eosin, together with photographic samples, have been deposited in the USNM, Beltsville, Maryland, USA (number 82820). Two other syntype histological slides stained in thionin have been deposited in the FDNR Marine Invertebrate Collection at FMRI, St. Petersburg, Florida (FSBC I 50409).

Developmental stages: Extrasporogonic stages were round to oval ( $\mathrm{n}=22$, mean diameter $=5.4 \times$ $5.6 \mu \mathrm{m}$, range $=3.0$ to $10.0 \mu \mathrm{m}$ ) and found only in the lumen of the kidney tubules. These stages included primary cells with 1,2 or 4 nuclei; uninucleate primary cells with 1,2 or 4 daughter cells; binucleate primary cells with $1,2,4,6$ or 8 daughter cells

Sporogonic stages: These were oval and contained 12 cells within a uninucleate or binucleate pseudoplasmodium in the lumen of the kidney tubules.

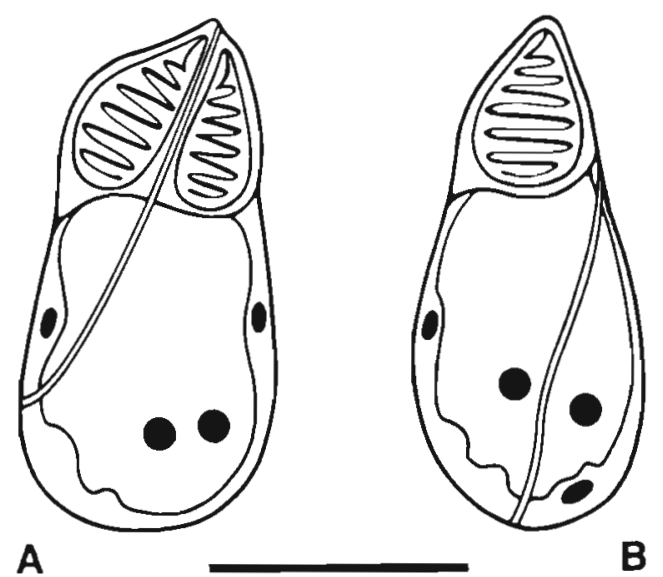

Fig. 1 Parvicapsula renalis n. sp. Line drawing of mature spores. (A) Front view; (B) side view. Scale bar $=5.0 \mu \mathrm{m}$

Spore characteristics: Mature spores were elongate, $9.5 \mu \mathrm{m}$ long (range 9.0 to $10.0 \mu \mathrm{m}, \mathrm{n}=15$ ), asymmetrical, and slightly curved. One valve was slightly larger than the other. The posterior spore was wider $(4.7 \mu \mathrm{m}$; range 4.0 to $5.0 \mu \mathrm{m}, \mathrm{n}=11$ ) than the anterior region (3.55 $\mu \mathrm{m}$; range 3.0 to $4.0 \mu \mathrm{m}, \mathrm{n}=11$ ) measured at the point parallel with the base of the polar capsules. Suture line extended through the anterior pole towards, but not necessarily bisecting, the posterior pole. Pyriform polar capsules $(3.0 \times 2.0 \mu \mathrm{m})$ pointed in towards each other and situated in a raised 'head' region that appeared to be separated from the spore cavity by a 'membrane'. The polar filaments had 5 to 8 evenly spaced coils.

\section{RESULTS}

Prevalence levels of Parvicapsula renalis $\mathrm{n} . \mathrm{sp}$. in red drum are reported in Table 1 Salinities in these areas ranged from 8.5 to $27.0 \mathrm{ppt}$. Both developmental stages

Table 1. Prevalence and geographic distribution of red drum kidney myxosporeans. Abbreviations as in the text

\begin{tabular}{|lcccc|}
\hline Site & $\begin{array}{r}\text { No. of } \\
\text { red drum } \\
\text { examined }\end{array}$ & $\begin{array}{c}\text { Standard } \\
\text { length } \\
\text { range }(\mathrm{cm})\end{array}$ & H. ocellata & P. renalis n. sp. \\
\hline SERF & 31 & $3.1-8.8$ & 0.0 & 0.0 \\
BH & & & & \\
Feral & 5 & $8.2-21.0$ & 0.0 & 0.0 \\
Tagged & 4 & $11.5-26.0$ & 25.0 & 0.0 \\
VC & & & & \\
Feral & 31 & $2.8-23.5$ & 0.0 & 6.5 \\
Tagged & 46 & $5.3-17.8$ & 0.0 & 13.0 \\
\hline
\end{tabular}



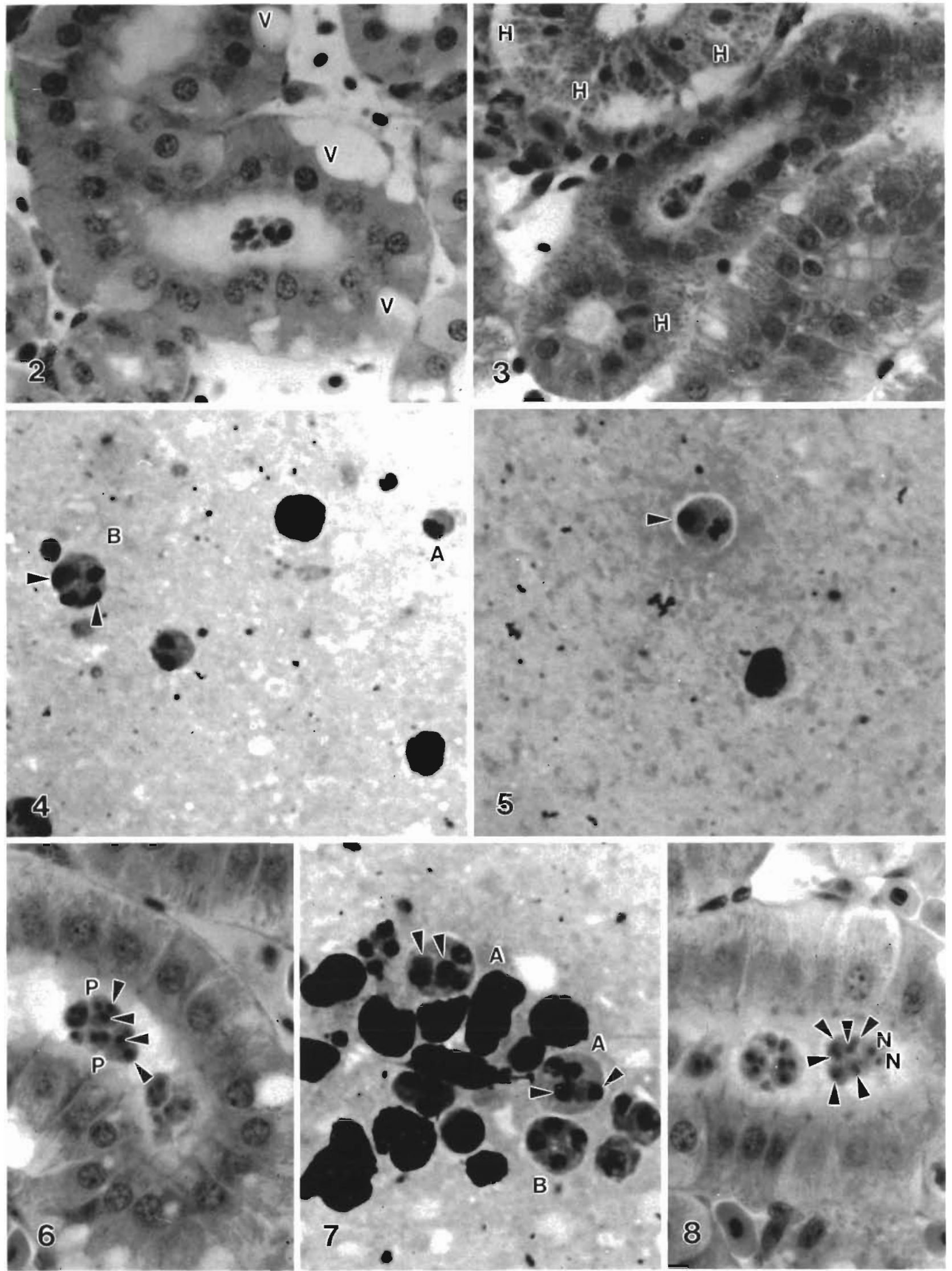

Figs. 2 to 20. Parvicapsula renalis n. sp. from posterior kidney of red drum Sciaenops ocellatus. Light micrographs of histological sections of kidney stained in thionin (Figs. 2, 3, 6, 8, 10, 12, 13, 17, 19, 21 \& 22), or of impression smears stained in Giemsa (Figs. $4,5,7 \& 9)$. Fresh squash preparations of immature and mature spores from kidney; observed using differential interference contrast microscopy (Figs. 11,14,15,16,18 \& 20). Fig. 2. Kidney tubule with intraluminal stages and vacuolation of epithelial cells. V: vacuolation. $\times 1000$. Fig. 3. Kidney tubule with intraluminal stages and formation of hyaline droplets in epithelial cells. H: hyaline droplets. $\times 1000$. Fig. 4. Parasite developmental stages. (A) Uninucleate primary cell; (B) binucleate primary cell with 2 daughter cells (arrows). $\times 1500$. Fig. 5. Uninucleate primary cell with 1 daughter cell (arrow) $\times 1500$. Fig. 6 . Kidney tubule with 


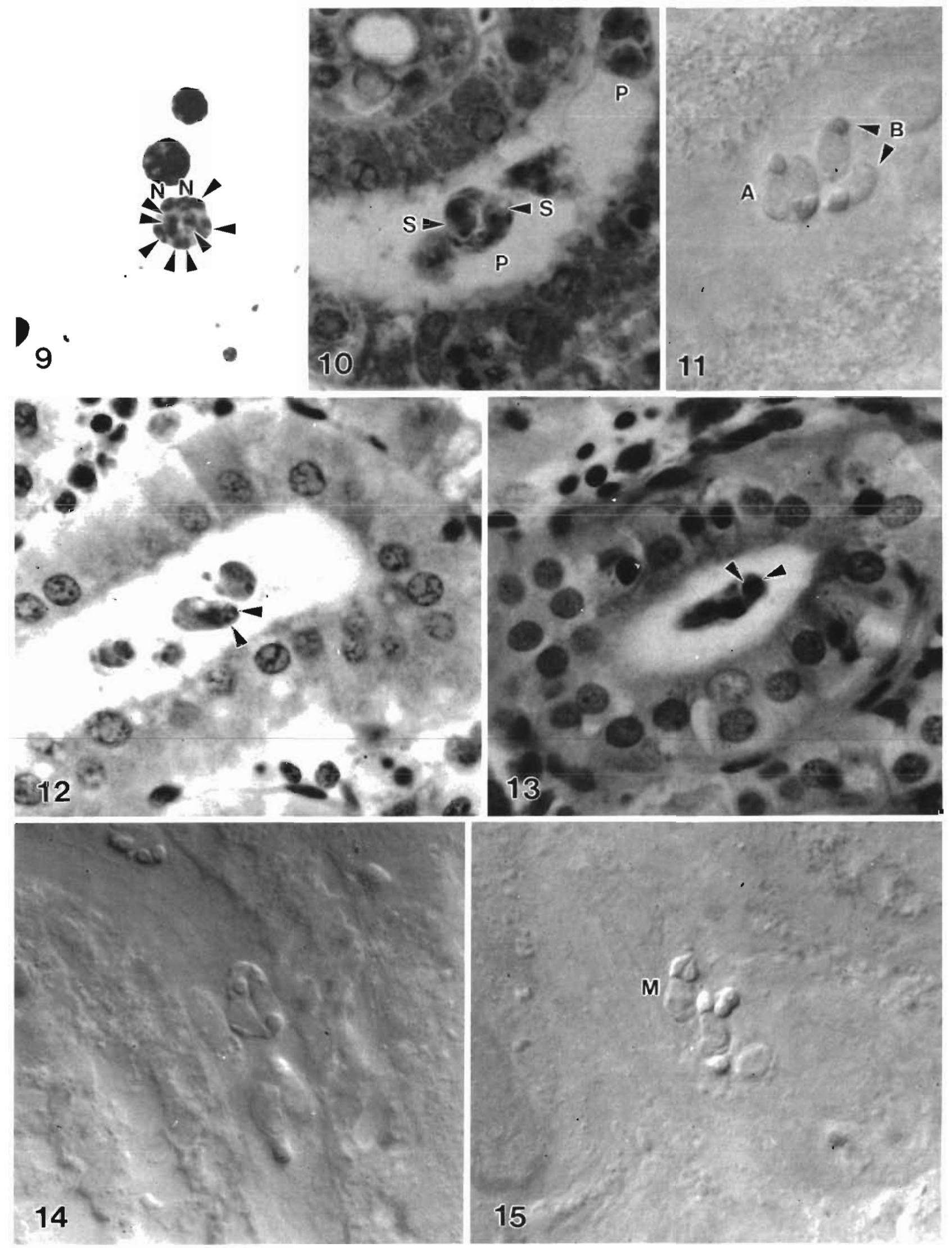

intraluminal stages showing uninucleate primary cells (P), each with 2 daughter cells (arrows). $\times 1000$. Fig. 7 . Developmental stages. (A) Two binucleate primary cells, each with 2 secondary cells (arrows); (B) 1 primary cell with 4 nuclei. $\times 1500$. Fig. 8. Kidney tubule with intraluminal stages. Binucleate $(\mathrm{N})$ primary cell with 6 daughter cells (arrows). $\times 1000$. Fig. 9 . Developmental stage. Binucleate $(\mathrm{N})$ primary cell and 8 daughter cells (arrows). $\times 1250$. Fig. 10. Developing pseudoplasmodia with sporoblasts $(S)$ in kidney lumen. P: pseudoplasmodia. $\times 1500$. Fig. 11. Disporous pseudoplasmodia. (A) Intact; (B) disrupted (arrows). $\times 1250$. Fig. 12. Immature spore with small polar capsules (arrows). $\times 1450$. Fig. 13. Elongate immature spore showing stained polar capsules (arrows). $\times 1150$. Fig. 14 . Elongate immature spores in fresh preparation. $\times 1250$. Fig. 15 . Front view of mature spore (M). 


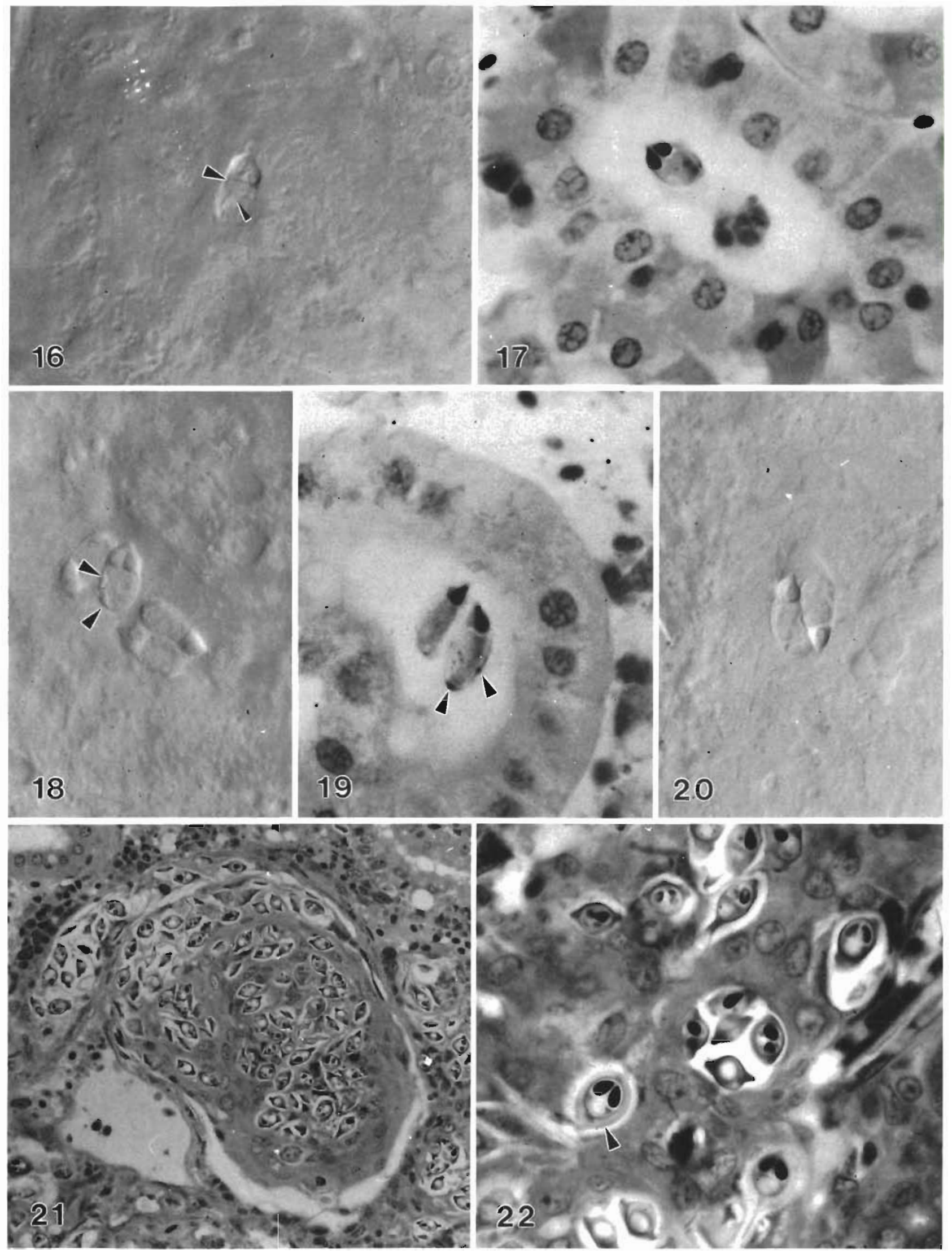

$\times 1200$. Fig. 16. Front view of mature spore showing thin suture line (thin arrow) and separation of head region trom spore cavity by 'membrane' (thick arrow). $\times 1250 \mathrm{~F} 1 \mathrm{~g} .17$. Mature spore staned to show position of polar capsules. $\times 1000$. Fig. 18 . Mature spore with valvogenic nuclei (arrows). $\times 1250$. Fig. 19 Staned mature spores showing position of valvogenic nucleı (arrows) $\times 1250$. Fig. 20. Side view of mature spores. $\times 1 \overline{250}$. Figs. $21 \& 22$. Henneguya ocellata Light micrographs of histological sections of posterior kidney stained in thionin Flg. 21. H. ocellata cyst showing mature spores $\times 400$ Fig 22 High magnification of mature spores showing characteristic sutural ridge (arrow) and position of polar capsules. $\times 1000$ 
and mature spores of $P$. renalis $n$. $s p$. were found during March, June and August, whereas only developmental. stages were found during September and October. Other samples were negative.

Histological sections of the posterior kidney showed developmental stages and spores of Parvicapsula renalis $\mathrm{n} . \mathrm{sp}$. in the proximal tubules. In 1 case, kidney hypertrophy was macroscopically detectable, and the kidney was about 3 times the normal size. No parasites were detected in the glomeruli, haematopoietic tissue or blood. In some fish, kidneys infected with intraluminal stages showed light to heavy vacuolation in the tubular epithelium (Fig. 2). In some cases, hyaline droplets were predominant in the tubular epithelium (Fig, 3), and in others, large numbers of rodlet cells were apparent.

\section{Extrasporogonic stages}

Early parasite stages were identified in impression smears and histological sections of posterior kidney. The frequencies of different types of developing stages identified from 1 impression smear stained in Giemsa are given in Table 2 . Stages included primary cells

Table 2. Parvicapsula renalis $\mathrm{n} . \mathrm{sp}$. Frequency and type of developmental stages of $P$. renalis $n$. sp. from 1 impression smear from red drum posterior kidney

\begin{tabular}{|ccc|}
\hline $\begin{array}{c}\text { Primary cell } \\
\text { (no. of nuclei) }\end{array}$ & Daughter cells & No. of cells \\
\hline 1 & - & 7 \\
2 & - & 14 \\
4 & - & 37 \\
- & 1 & $13^{\circ}$ \\
& & \\
1 & 1 & 20 \\
1 & 2 & 13 \\
1 & 4 & 9 \\
& & 3 \\
2 & 1 & 71 \\
2 & 2 & 18 \\
2 & 4 & 9 \\
2 & 6 & 6 \\
2 & $8 \quad(=2 \times 4)$ & \\
a Daughter cell released & & \\
\hline
\end{tabular}

with 1 (Fig. 4), 2 or 4 (Fig. 7, needs confirmation by electron microscopy) light-mauve nuclei, a light-blue cytoplasm, but no daughter (future sporogonic) cells. Within primary cells in other stages, distinct daughter cells with a deep-blue cytoplasm and a darkly staining, mauve nucleus were present. Uninucleate primary cells containing 1 (Fig. 5), 2 (Fig 6) or 4 daughter cells were present but were not as common as binucleate primary cells with 1,2 (Figs. $4 \& 7$ ), 4, 6 (Fig. 8) or 8 (either $2 \times 4$ or 8 ) (Fig. 9) daughter cells.

\section{Sporogonic stages}

In later stages of development of the 'pseudoplasmodia' (primary cell and developing sporoblasts), 2 groups of 6 sporogonic (formerly daughter) cells formed separate sporoblasts (Fig. 10). Pseudoplasmodia usually had a primary cell with 1 or 2 primary nuclei and were disporous (Fig. 11). Immature spores appeared to have small polar capsules (Fig. 12) and were extremely elongate (Figs. 13 \& 14).

In front view, mature spores were elongate, $9.5 \mu \mathrm{m}$ long (range 9.0 to $10.0 \mu \mathrm{m}, \mathrm{n}=15$ ), asymmetrical, and slightly curved (Fig. 15). One valve was slightly larger than the other. The posterior spore was wider $(4.7 \mu \mathrm{m}$; range 4.0 to $5.0 \mu \mathrm{m}, \mathrm{n}=11$ ) than the anterior region (3.55 $\mu \mathrm{m}$; range 3.0 to $4.0 \mu \mathrm{m}, \mathrm{n}=11$ ) measured at the point parallel with the base of the polar capsules. The barely noticeable suture line extended through the anterior pole towards, but not necessarily bisecting, the posterior pole. In some cases the line appeared to run through the polar capsules (Fig. 16). The polar capsules were situated in a raised 'head' region and appeared to be separated from the spore cavity by a 'membrane' (length of cavity to anterior tip $=3.3 \mu \mathrm{m}$; range 3.0 to $4.0 \mu \mathrm{m}, \mathrm{n}=15$ ) (Fig. 16). The pyriform polar capsules had an average length of $3.0 \mu \mathrm{m}$ (range 2.5 to $3.0 \mu \mathrm{m}, \mathrm{n}=15$ ) and width of $2.0 \mu \mathrm{m}$ (range 1.5 to $2.0 \mu \mathrm{m}, \mathrm{n}=15$ ) and pointed in towards each other (Fig. 17). The polar filaments appeared to have 5 to 8 evenly spaced coils. The valves were uneven and their nuclei projected into the spore cavity in fresh specimens (Fig. 18). Valvogenic nuclei were also quite distinct in thionin-stained spores (Fig. 19). In side view, mature spores were conical, with the posterior end wider (4.25 $\mu \mathrm{m}$; range 4.0 to $5.0 \mu \mathrm{m}, \mathrm{n}=4$ ) than the anterior region ( $3.0 \mu m_{\text {; }}$ no range, $n=4$ ) measured at the point parallel with the base of the polar capsule (Fig. 20). The sporoplasm was binucleate.

\section{Henneguya ocellata Iversen \& Yokel, 1963}

In 1 tagged red drum ( $\mathrm{SL}=19.0 \mathrm{~cm}$ ) sampled from Bishop's Harbor, several histozoic myxosporean cysts containing mature spores (Table 1) were confirmed as Henneguya ocellata (Iversen. \& Yokel 1963). The cysts were polysporous and were located in the posterior kidney (Fig. 21). Spore measurements were as follows: total length $=25.0 \mu \mathrm{m}$ (range 19.0 to $29.0 \mu \mathrm{m}, \mathrm{n}=8$ ), breadth $=7.3 \mu \mathrm{m}$ (range 6.0 to $8.0 \mu \mathrm{m}, n=1.2$ ), thick- 
ness $=5.0 \mu \mathrm{m}$ (range 4.0 to $6.0 \mu \mathrm{m}, \mathrm{n}=13$ ), polar capsule length $=3.2 \mu \mathrm{m}$ (range 3.0 to $4.0 \mu \mathrm{m}, \mathrm{n}=12$ ), polar capsule width $=2.0 \mu \mathrm{m}$ (no range, $\mathrm{n}=12$ ). The distinct, heavy sutural ridge noted by Iversen \& Yokel (1963) was also confirmed (Fig. 22)

\section{DISCUSSION}

The only previously recorded myxosporean from red drum is Henneguya ocellata, which was present in the intestine (Iversen \& Yokel 1963). The cysts found in the kidney in the present study were confirmed as $H$. ocellata and represent localization in a new tissue site.

Four species of Parvicapsula have previously been described from the lumen of the urinary bladder of marine fish. These are $P$. asymmetrica (Shulman 1953) in Cyclopterus lumpus; P. lobata (= Ceratomyxa lobata Evdokimova 1977) (Gaevskaya et al. 1982) in Austroatherina incisa; $P$. schulmani (Kovaleva \& Gaevskaya 1981) in Beryx splendens; and P. unicornis (Kabata 1962) in Callionymus lyra, Limanda limanda and Lepidorhombus whiffiagonis. In addition, Parvicapsula $\mathrm{sp}$. was reported from the kidney of Oncorhynchus kisutch (Hoffman 1981, Johnstone 1984). This latter species caused chronic proliferative nephritis and apparently, significant mortality in cultured fish. Developmental stages and mature spores were histozoic in the renal tubule epithelium, and mature spores were also found in the tubular lumen. Unlike $P$. renalis $\mathrm{n}$. $\mathrm{sp}$., both $P$. unicornis and $P$. lobata have a distinct extension of the spore at the acapsular pole. The ratio of polar capsule length to spore length is much greater in $P$. asymmetrica $(1: 6.6$ to 10.0$)$, $P$. schulmani (1:6.0) and Parvicapsula sp. (1:7.0 to 10.0) than in $P$. renalis n. sp. (1:3.2), which has proportionately larger polar capsules. In Parvicapsula sp., the only other species recorded from the kidney, development was histozoic and disporoblastic and/or pansporoblastic (Johnstone 1984). In P. renalis n. sp., development was coelozoic and disporoblastic. $P$. renalis $\mathrm{n}, \mathrm{sp}$. thus appears, with respect to spore morphology, geographical area, site location, development and host specificity, to be a different species than those previously described.

Pathological changes similar to those seen here in renal tissue have been described in Sphaerospora spp. Dyková \& Lom (1982) noted hyaline droplet degeneration and vacuolisation of renal epithelial cells associated with $S$. renicola which, in severe cases, led to nephrosis and necrosis of the tubular epithelium. Desser et al. (1983) and Supamattaya et al. (1991) also noted vacuolation of renal tubule epithelial cells in fish infected with $S$. angulata and $S$. epinepheli, respectively.
Based on the types and the relative frequencies of developmental stages found in the kidney, it is postulated that the life cycle of Parvicapsula renalis n. $\mathrm{sp}$. may have the following sequence. Primary cells with 1 or 2 nuclei give rise, either by endogeny or binary fission, to 1, 2 or 4 daughter cells. Division continues in a synchronous or an asynchronous manner until, in advanced stages, binucleate primary cells include 6 or 8 daughter (sporogonic) cells, which eventually form 2 groups (sporoblasts) of 6 cells. The 6 sporogonic cells in each sporoblast develop into the 2 valvogenic 2 capsulogenic and 2 sporoplasm cells that constitute a spore. Each enveloping (formerly primary) cell surrounding the 2 spores of the pseudoplasmodium usually has 2 nuclei, although 1 nucleus may also be possible. This hypothetical life cycle needs confirmation through more detailed study.

The sequential development of Parvicapsula renalis n. sp. in the kidney of red drum appears to be similar to that of Sphaerospora spp. in the posterior kidney of other fish. Sphaerospora spp. usually form a pseudoplasmodium with a uninucleate primary cell and a series of daughter cells, which eventually transform into sporoblasts. Development may be monosporous, as in S. ictaluri (Hedrick et al. 1990); disporous, as in S. renicola (Dyková \& Lom 1982) and S. angulata (Desser et al. 1983); or both, as in $S$. epinepheli (Supamattaya et al. 1991). The difference between the development of Sphaerospora spp. and $P$. renalis $\mathrm{n}$. $\mathrm{sp}$. as described here appears to be the presence of 2 nuclei in the primary (envelope) cell of the pseudoplasmodium in $P$. renalis n. sp. In Sphaerospora spp., only 1 nucleus is present in the primary cell (Lom et al. 1982). In Parvicapsula sp., both disporoblasts and pansporoblasts developed in renal tubule epithelia, but the number of nuclei in the disporoblast is unclear (Johnstone 1984). Developmental stages of other Parvicapsula spp. have not been well described.

It is interesting to note some similarities between the developmental stages of Parvicapsula renalis $\mathrm{n}$. sp. and those of PKX, the enigmatic myxosporean that causes proliferative kidney disease, primarily in salmonids. Mature spores of PKX have never been isolated, although 2 studies have shown evidence of immature spores (Kent \& Hedrick 1986, Clifton-Hadley \& Feist 1989). The immature spores pictured in these latter 2 studies bear a remarkable likeness to the immature spores of $P$. renalis n. sp. (Figs. 12 to 14), and appear to be more elongate than Sphaerospora spp. spores, to which they are often compared. However, possible relationships to Parvicapsula spp. have been recognised (Kent \& Hedrick 1986, Clifton-Hadley \& Feist 1989). The PKX forms intraluminally in kidney tubules as pseudoplasmodia with primary, secondary and tertiary cells (Kent \& Hedrick 1986). Unlike Sphaerospora spp. 
in which the pseudoplasmodium has uninucleate enveloping cells (Lom et al. 1982), and like $P$. renalis n. sp., described here with binucleate enveloping cells, PKX usually has 2 or 3 nuclei in the envelope cell of the pseudoplasmodium (Kent \& Hedrick 1986). Ultrastructural study is required to confirm the life-cycle sequence and relationship of $P$. renalis $\mathrm{n}$. $\mathrm{sp}$. to other kidney Parvicapsula and Sphaerospora species and to PKX

Acknowledgements. The research described in this study was supported by funding from the Department of the Interior U.S. Fish and Wildlife Service, Federal Aid for Sportfish Restoration, Project Number F-44. I thank Kathy Childress for providing fish; Noretta Perry and Barbara Blakesley for histological and photographic support; Ruth Reese, Judy Leiby, William Lyons and David Camp for their comments on the manuscript; and Llyn French for drawings

\section{LITERATURE CITED}

Clifton-Hadley, R. S., Feist, S. W. (1989). Proliferative kidney disease in brown trout Salmo trutta: further evidence of a myxosporean etiology. Dis. aquat. Org. 6: 99-103

Desser, S. S., Molnar, K., Horvath, I. (1983). An ultrastructural study of the myxosporeans Sphaerospora angulata and Sphaerospora carassii in the common carp, Cyprinus carpio. J. Protozool. 30: 415-422

Dyková, I., Lom, J. (1982). Sphaerospora renicola n. sp., a myxosporean from carp kidney, and its pathogenicity. Z. Parasitkd. 68: 259-269

Evdokimova, E. B. (1977). Myxosporidia of Patagonian shelf teleosts (Atlantic shore of Argentina). Parazitologiya 11: $166-178$

Gaevskaya, A. V., Koveleva, A. A., Shulman, S. S. (1982). Neoparvicapsula gen. n. and the position of the family
Parvicapsulidae in the system of the Myxosporidia. Zool. Zh. 61: 774-777

Hedrick, R. P., McDowell, T., Groff, J. M. (1990) Sphaerospora ictaluri n. sp. (Myxosporea: Sphaerosporidae) observed in the kidney of channel catfish, Ictalurus punctatus Rafinesque. J. Protozool. 37: 101-112

Hoffman, G. L. (1981). The fish pathogens, Parvicapsula sp. and Mitraspora cyprini Myxosporea, new to North America. In: Olah, J., Molnar, K., Jeney, Z. (eds.) Fish, pathogens and environment in European polyculture. Fisheries Research Institute, Szarvas, p. 184-197

Iversen, E. S., Yokel, B. (1963). A rnyxosporidian (sporozoan) parasite in the red drum, Sciaenops ocellatus. Bull. mar. Sci. Gulf Caribb. 13: 449-453

Johnstone, A. K. (1984). Pathogenesis and life cycle of the myxozoan Parvicapsula sp. infecting marine cultured coho salmon. Ph.D. thesis, University of Washington, Seattle

Kabata, Z. (1962). Five new species of Myxosporidia from manne fishes. Parasitology 52: 177-186

Kent, M. L.. Hedrick, R. P. (1986). Development of the PKX myxosporean in rainbow trout Salmo gairdneri. Dis. aquat. Org. 1. 159-182

Kovaleva, A. A., Gaevskaya, A. V. (1981). On new records of myxosporidians of the genus Parvicapsula from Atlantic fishes. Zool. Zh. 60: 771-773

Lom, J., Dyková, I., Lhotáková, S. (1982). Fine structure of Sphaerospora renicola Dyková and Lom, 1982, a myxosporean from carp kidney and comments on the origin of pansporoblasts. Protistologica 18: 489-502

Quintero-Hunter, I., Grier, H., Muscato, M. (1991). Enhancement of histological detail using metanil yellow as a counterstain in periodic acid/Schiff's hematoxylin staining of glycol methacrylate tissue sections. Biotech. Histochem. 66: 169-172

Shulman, S. S. (1953). New and little known Sporozoa of the White Sea. Zool. Zh. 32: 1481-1497

Supamattaya, K., Fischer-Scherl, T., Hoffmann, R. W. Boonyaratpalin, S. (1991). Sphaerospora epinepheli n. sp. (Myxosporea: Sphaerosporidae) observed in grouper (Epinephelus malabaricus). J. Protozool. 38: 448-454

Manuscript first received: March 22, 1993

Revised version accepted: July 6, 1993 